\title{
DETERMINANT FACTORS OF VASECTOMY METHOD SELECTION
}

\author{
Esti Yunitasari, Retnayu Pradanie, Hardiansyah Hardiansyah \\ Faculty of Nursing Universitas AirlanggaKampus C, Mulyorejo, Surabaya, \\ Telp/Fax: (031) 5913754, \\ Email: esti-y@fkp.unair.ac.id
}

\begin{abstract}
Introduction: The level of male participation in family planning by choosing vasectomy in East Lampung region Pekalongan health centres is still low, although the success rate of vasectomy as a family planning method is very high. This study aims to explain the factors related to men's choice of vasectomy in the Pekalongan health center East Lampung. Methods: This study used an analytical study design with a cross-sectional approach. Samples were 117 men of reproductive age gathered using purposive sampling. The independent variables were knowledge, attitudes, parity, age, availability of health resources and infrastructure, health education, attitude and behaviour of health care workers and family support. The dependent variable was the men's participation in vasectomy as a family planning method. Data were retrieved using questionnaires and statistically analysed using the Chi-Square test. Results: Factors affecting the selection of vasectomy as a family planning method amongst men of reproductive age were attitude $(p=0.020)$, parity $(p=0.022)$, age $(\mathrm{p}=0.021)$, the availability of health resources and health infrastructure $(\mathrm{p}=0.018)$, and family support $(\mathrm{p}=0.011)$. However, the knowledge, health education, and the attitudes and behaviour of health workers did not affect the selection of vasectomy as a family planning method. Conclusiom: Public health centres are expected to build family planning services, especially for vasectomies, through, for example, the provision of vasectomy facilities which can reach the community and the establishment of cadres for male birth control.
\end{abstract}

Keywords: family planing; vasectomy; Lawrence Green

\section{INTRODUCTION}

Population problems in Indonesia include a large population with a relatively high rate of population growth. The Indonesian Population and Family Planning Agency (BKKBN) has a role in increasing the use of contraception (Badan Kependudukan dan Keluarga Berencana Indonesia (BKKBN) 2016). Some family planning institutions are oriented towards contraceptive use in women rather than in men, but the results of contraceptive method surveys in various countries show that $50 \%$ of couples use condoms and vasectomies as contraceptives (Anderson \& Baird 2002). Some women cannot use contraception due to their health condition, so many men take over to use contraception to prevent unintended pregnancies (Amory 2016).

Male participation is one of the indicators of success for a contraception program in creating a small family with qualities. The participation of the male/husband could be direct or indirect. Direct participation is using a contraception method such as a condom, vasectomy, coitus interruptus, or the periodic abstention method (BKKBN 2005).

In Indonesia, the achievement of family planning goals for participants with long-term contraception methods (vasectomy, tubectomy, implant and Intra Uterine Device (IUD)) in 2015 is very high, exceeding the target that has been set at 103.9\% (BKKBN 2016).

Males who actively followed the contraception program and preferred to choose a vasectomy were 148,560 persons in total (11.9\%), and there were $1,099,380$ other persons $(89.1 \%)$ using a condom as contraception (BKKBN 2015). Data from BKKBN (2014) in Lampung Province show that 86 persons have chosen a vasectomy from a total of 47,268 males who joined the active contraception program, while the number of males who used a condom as contraception reached 20,068. Based on these data, it was revealed that the East Lampung Regency had the lowest number of males using vasectomy three persons out of 10 members who were eligible for vasectomy contraception.

Pekalongan has the highest number of men of reproductive age in the East Lampung Regency, but the presentation of vasectomy contraceptive participation was only $2.3 \%$ of the total number of men using contraceptives. The majority of those were located in Sidodadi, part of a community health centre at Pekalongan (Pekalongan, 2015).

Vasectomy is one effective method of contraception, as seen from the high success rate, that it is safe and has no long- 
term side effects (Chang et al. 2015). The cost for vasectomy is relatively cheap and affordable, and, additionally, many men are eligible to use vasectomy. However, men still prefer to use other contraceptive methods such as condoms (BKKBN, 2015).

Men who use condoms argue that condoms are simpler and require no action from medical staff, are available in stores, pharmacies, leave them free to choose, and do not interfere with sexual intercourse. But, in fact, condoms can not be used in the long term, there is still a risk of leakage, discomfort during sex, and they can reduce the sensitivity of the penis (Tejo, 2009). Factors related to the use of vasectomy are still not known. Based on that phenomenon this study aims to determine the factors related to the selection of vasectomy as a contraceptive method amongst men of reproductive age in Pekalongan East Lampung.

\section{METHOD}

This study was an analytical study with a cross sectional design. The population in this study were men of reproductive age who actively use contraception in Puskesmas Pekalongan East Lampung Regency. Samples were 117 respondents selected using a purposive sampling technique, often called judgment sampling. The independent variables in this study were the knowledge, attitudes, number of children, age, availability of health resources and infrastructure, health education, attitude and behaviour of health care workers, and family support. The dependent variable was the selection of vasectomy.

The research instrument used questionnaires that were composed based on the theory dependant on the study variables. The questionnaire's validity and reliability were tested first before they were used for data collection. Data obtained were then processed using a descriptive analysis and Chi- Square data analysis with $95 \%$ significance $(\alpha \leq 0.05)$. This study has been through the ethical clearance test at the Faculty of Nursing Universitas Airlangga with a serial number 287-KEPK.

\section{RESULTS}

The number of men who chose vasectomy as a method of contraception in this study was lower when compared with the number of men who chose another male contraceptive method. The correlation between knowledge and vasectomy selection amongst the men is described in Table 1 . The majority of respondents had a sufficient level of knowledge. The Chi-Square analysis test demonstrated that there was no correlation between knowledge and vasectomy selection.

The attitude of the respondents either in the vasectomy and non-vasectomy group were mostly in a positive category. Respondents who participated as vasectomy acceptors had a positive attitude; it was higher than in the nonvasectomy group. Non-vasectomy respondents had a negative attitude. This means that there was a correlation between attitude and vasectomy selection as shown by the statistical test (Table 2).

The number of children was usually a factor that could be a consideration in choosing the contraceptive method. Most respondents had more than three children (69.2\%). This statement was supported by the Chi-Square statistical test which was obtained showing that there was a correlation between the number of children and vasectomy selection $(\mathrm{p}=0.022)$ (Table 3$)$.

Table 1 The correlation of knowledge and vasectomy selection using a Chi-Square Test

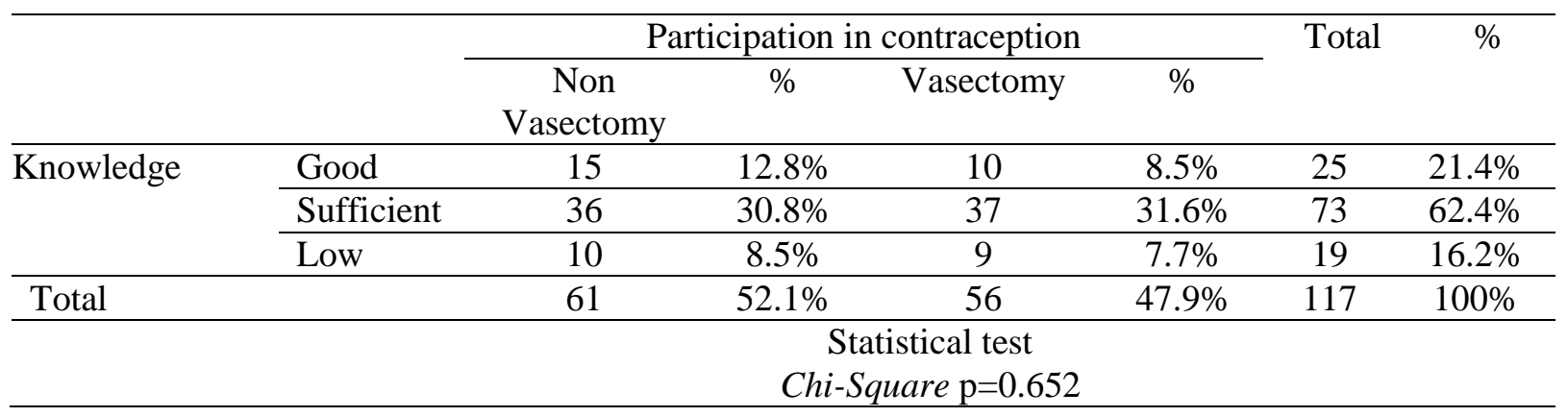


Determinant Factors of Vasectomy (Esti Yunitasari, et. al.)

Table 2 The correlation of attitude and vasectomy selection using a Chi-Square Test

\begin{tabular}{llcccccc}
\hline & & \multicolumn{3}{c}{ Participation in contraception } & Total & $\%$ \\
\cline { 2 - 7 } & & Non Vasectomy & $\%$ & Vasectomy & $\%$ & & \\
\hline Attitude & Negative & 37 & $31.6 \%$ & 21 & $17.9 \%$ & 58 & $49.6 \%$ \\
\cline { 2 - 7 } & Positive & 24 & $20.5 \%$ & 35 & $29.9 \%$ & 59 & $50.4 \%$ \\
\hline Total & 61 & $52.1 \%$ & 56 & $47.9 \%$ & 117 & $100 \%$ \\
\hline \multicolumn{7}{c}{$\begin{array}{c}\text { Statistical test } \\
\text { Chi-Square } \mathrm{p}=0.020\end{array}$} \\
\hline
\end{tabular}

Table 3 The correlation between the number of children with vasectomy selection

\begin{tabular}{|c|c|c|c|c|c|c|c|}
\hline & & \multicolumn{4}{|c|}{ Participation in contraception } & \multirow[t]{2}{*}{ Total } & \multirow[t]{2}{*}{$\%$} \\
\hline & & $\begin{array}{c}\text { Non } \\
\text { Vasectomy }\end{array}$ & $\%$ & Vasectomy & $\%$ & & \\
\hline \multirow[t]{2}{*}{ Parity } & 2 children & 25 & $21.4 \%$ & 11 & $9.4 \%$ & 36 & $30.8 \%$ \\
\hline & More than 3 & 36 & $30.8 \%$ & 45 & $38.5 \%$ & 81 & $69.2 \%$ \\
\hline Total & & 61 & $52.1 \%$ & 56 & $47.9 \%$ & 117 & $100 \%$ \\
\hline \multicolumn{8}{|c|}{$\begin{array}{c}\text { Statistical test } \\
\text { Chi-Square } \mathrm{p}=0.022\end{array}$} \\
\hline
\end{tabular}

Table 4 The correlation of age with vasectomy selection

\begin{tabular}{|c|c|c|c|c|c|c|c|}
\hline & & \multicolumn{4}{|c|}{ Participation in contraception } & \multirow[t]{2}{*}{ Total } & \multirow[t]{2}{*}{$\%$} \\
\hline & & $\begin{array}{c}\text { Non } \\
\text { Vasectomy }\end{array}$ & $\%$ & Vasectomy & $\%$ & & \\
\hline \multirow[t]{2}{*}{$\overline{\text { Age }}$} & Less than 30 & 15 & $12.8 \%$ & 4 & $3.4 \%$ & 19 & $16.2 \%$ \\
\hline & More than 30 & 46 & $39.3 \%$ & 52 & $44.4 \%$ & 98 & $83.8 \%$ \\
\hline Total & & 61 & $52.1 \%$ & 56 & $47.9 \%$ & 117 & $100 \%$ \\
\hline \multicolumn{8}{|c|}{$\begin{array}{c}\text { Statistical test } \\
\text { Chi-Square } \mathrm{p}=0.021\end{array}$} \\
\hline
\end{tabular}

Table 5 The Correlation of health resources and infrastructure availability with vasectomy selection

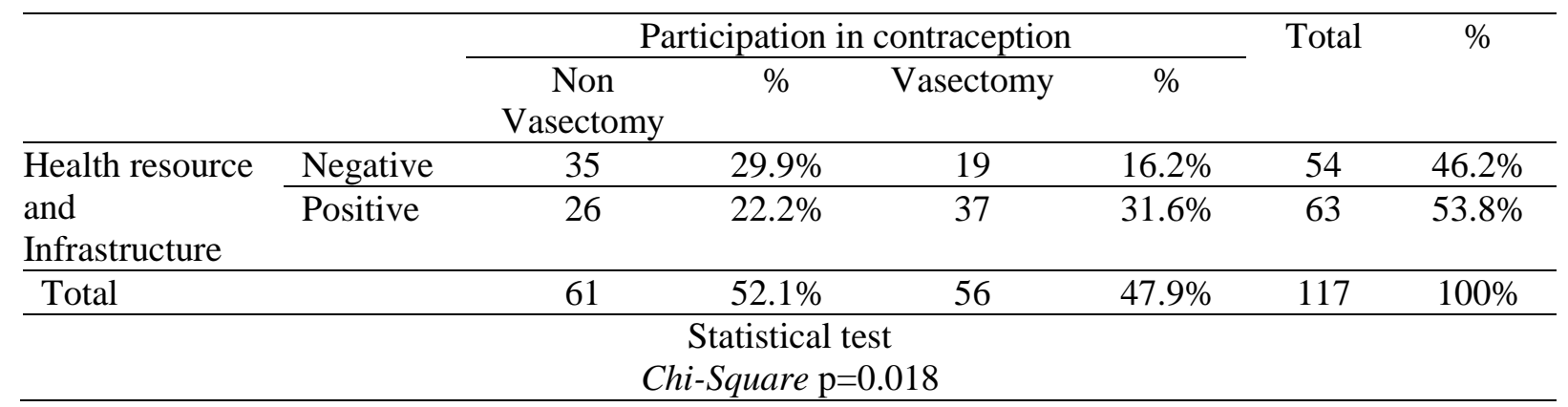

Table 6 The correlation of health education with vasectomy selection

\begin{tabular}{llcccccc}
\hline & & \multicolumn{3}{c}{ Participation in contraception } & Total & $\%$ \\
\cline { 2 - 7 } & \multicolumn{2}{c}{$\begin{array}{c}\text { Non } \\
\text { Vasectomy }\end{array}$} & $\%$ & Vasectomy & $\%$ & & \\
\hline Health & 47 & $40.2 \%$ & 36 & $30.8 \%$ & 83 & $70.9 \%$ \\
\hline Education & Never & 14 & $12.0 \%$ & 20 & $17.1 \%$ & 34 & $29.1 \%$ \\
\hline Total & 61 & $52.1 \%$ & 56 & $47.9 \%$ & 117 & $100 \%$ \\
\hline \multicolumn{7}{c}{$\begin{array}{c}\text { Statistical test } \\
\text { Chi-Square } \mathrm{p}=0.188\end{array}$} \\
\hline
\end{tabular}


Table 7 The correlation of attitude and behaviour of health workers with vasectomy selection

\begin{tabular}{llcccccc}
\hline & \multicolumn{3}{c}{ Participation in contraception } & Total & $\%$ \\
\cline { 2 - 7 } & & $\begin{array}{c}\text { Non } \\
\text { Vasectomy }\end{array}$ & $\%$ & Vasectomy & $\%$ & & \\
\hline $\begin{array}{l}\text { Attitude and } \\
\text { Behaviour }\end{array}$ & Negative & 18 & $15.4 \%$ & 9 & $7.7 \%$ & 27 & $23.1 \%$ \\
\hline Positive & 43 & $36.8 \%$ & 47 & $40.2 \%$ & 90 & $76.9 \%$ \\
\hline Total & 61 & $52.1 \%$ & 56 & $47.9 \%$ & 117 & $100 \%$ \\
\hline \multicolumn{7}{c}{$\begin{array}{c}\text { Statistical test } \\
\text { Chi-Square } \mathrm{p}=0.133\end{array}$} \\
\hline
\end{tabular}

Table 8 The correlation of family support with vasectomy selection

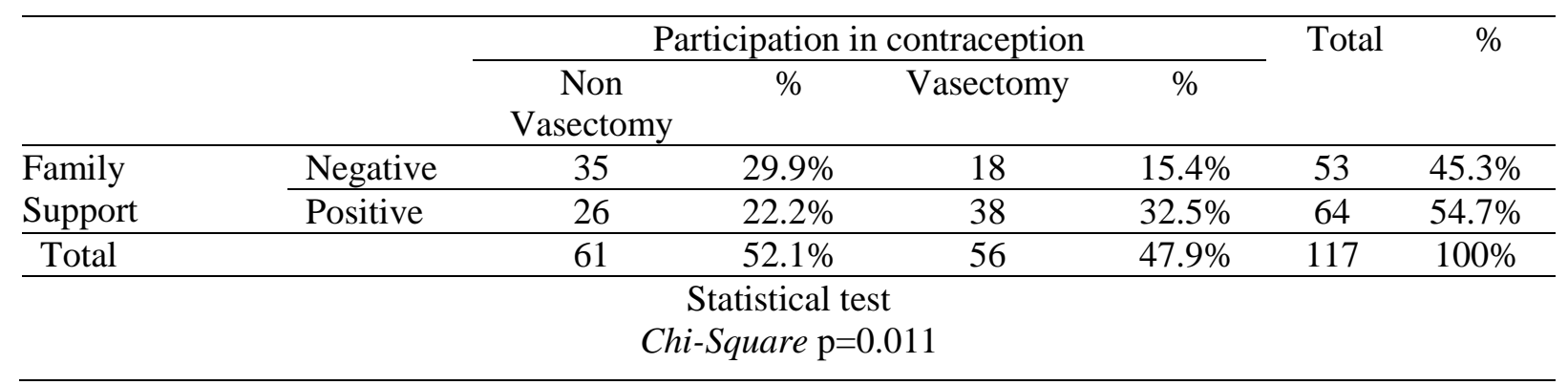

The most common age of respondents who participated in choosing a vasectomy as contraceptive method was more than 30 years old $(44.4 \%)$, while in the non-vasectomy group the number of respondents who were older than 30 totalled $39.3 \%$. The results of the correlation analysis using the ChiSquaresquare statistical test revealed the significant value of $p=0.021$, which means that there was a relationship between age and vasectomy selection (Table 4).

The availability of health resources and infrastructure both in the vasectomy and nonvasectomy group were in a positive category (53.8\%). Respondents who participated in the vasectomy group had positive health resources and infrastructure $(31.6 \%)$, while in the nonvasectomy group the percentage was only $22.2 \%$. The results of the Chi-Square test

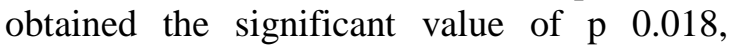
which means there was a relationship between health resources and infrastructure, and vasectomy selection (Table 5).

Based on Table 6, the majority of respondents $(70.9 \%)$ never received health education about contraception, especially vasectomy. However, the number of respondents in the vasectomy group who did totalled $47.9 \%$. This indicates that health education did not have a significant effect on the selection of contraceptive method as shown by a statistical test using Chi-Square which had $\mathrm{p}=0.188$.

The majority of health workers already had a positive attitude and behaviour (76.9\%). However, this fact was not the dominant factor affecting the decision of the respondents to choose a particular contraceptive method. It can be seen from the results of a statistical test using Chi-Square that there was no correlation between attitude and behaviour of health workers with vasectomy selection with $\mathrm{p}=0.133$ (Table 7).

The last factor considered in this study in correlation with vasectomy selection method was family support. Table 8 showed that $35(29.9 \%)$ respondents mentioned that they had negative family support in choosing a contraceptive method, in the non-vasectomy group, while $38(32.5 \%)$ respondents in the vasectomy group had positive family support. This number indicated that respondents who had selected vasectomy as their contraception had higher positive family support than those in the non-vasectomy group. By using a ChiSquare test, the p-value was 0.011 , meaning that family support was a contributory factor in respondents choosing to participate in a vasectomy or not. 


\section{DISCUSSION}

The knowledge level of respondents about vasectomy was at an insufficient level. This might be due to the level of education of many respondents who had junior and senior high school levels of education. The vasectomy method is usually used by men who have a good level of education (Wespes 2014). The results of a study in Taiwan showed that men who chose vasectomy had a high education $(68,5 \%$ had graduate degrees) (Chang et al. 2015).

According to Mubarak (2007) the higher level of education could mean the information is more easily transferred and received, and ultimately the more knowledge could be gained. Conversely, if the level of education is low, it will hinder the development of one's attitude to receiving information and newly introduced values. However, the number of non-vasectomy respondents was higher than respondents who participate actively by using vasectomy and there were still some respondents who had good knowledge but did not participate in vasectomy. This means that the level of knowledge does not guarantee a person will commit an act or demonstrate a type of behavioural health. Skinner (1938) in Notoatmodjo (2012) stated that behaviour is a person's reaction to a stimulus from the outside, but in responding, it depends on the characteristics or other factors of the person concerned. This means that even though the stimulus is the same for some people, the response of each person is different. This can also be caused by misunderstandings and negative rumours about vasectomy that causes a person to be reluctant to choose a vasectomy (Bunce, A., Guest, G., Searing, H., Frajzyngier, V., Riwa, P., Kanama, J.,Achwal 2007).

There were respondents who had a low level of knowledge who participated actively in vasectomy. This can occur as a result of a persuasive family planning program from the government, so that whoever participates in using a vasectomy will be given money, so even though respondents have less knowledge, they still participate in a vasectomy program. From the analysis, there was no correlation between knowledge and the selection of vasectomy. This means that a good knowledge of vasectomy does not affect a man's decision to choose a vasectomy. The results of this study are supported by other studies which suggest that income, knowledge, age and attitude of public figures does not affect the use of vasectomy contraception (Muklison 2015).

The results of the study in the distribution frequency of attitudes towards vasectomy selections showed that more respondents had a positive attitude than a negative one. A positive attitude towards vasectomy is determined by respondents' votes for vasectomy themselves. A positive attitude arises from positive beliefs. The total number of respondents who had a positive attitude mostly used vasectomy rather than nonvasectomy, but those who had a negative attitude mostly did not participate in using vasectomy. Attitude is a reaction or response which was still closed from one to a stimulus or object (Notoatmodjo 2012). According to Allport in Notoatmodjo (2012) components that are built into attitude are: 1) faith (belief), ideas and concepts, to an object; 2) the emotional life or evaluation of an object; 3 ) the tendency to act. Thus, a person's belief or conviction about an object affect the action to be performed.

The analysis of attitude in relation to vasectomy selections showed that there were respondents who had a positive attitude but did not use vasectomy, as well as respondents who had a negative attitude but participated actively in vasectomy. This happens as a result of the government's program on vasectomy in East Lampung. There are two kinds of community participation methods according to Notoadmojo (2012): participation by coercive means to force the public to contribute to the program (through legislation, regulations or verbal commands), then, secondly, participation by persuasion and education. Positive trust will form a positive attitude. Furthermore, a positive attitude develops a person's tendency to act positively as well. If someone has negative beliefs or a negative concept, it will form a negative attitude then create a difficulty to act positively.

On the other hand, the number of children could be one of the factors that affected men's decisions to participate in vasectomy selection. In Indonesia, the number of children is often related to economic status. 
Most respondents worked as farmers and had a low income per month. Pratiwi in her research (2011) mentioned that family income was an indicator of economic factors, and affects the number of children born to a family. Respondents who have more than three living children have a tendency to more actively participate in vasectomy than respondents who have two children. This is because vasectomy is more effective than other types of contraceptive method for men so that respondents prefer to choose vasectomy to terminating a pregnancy. The effectiveness of vasectomy is in the range between $99.6 \%$ $99.8 \%$; it is very safe and has no long term side effects, only once it is applied, it is effective in the long term, and cost efficient (Saifuddin et al. 2010).

There was a correlation between the number of children and vasectomy selection. This means that respondents who had more than three children had more of a tendency to participate in the selection of vasectomy, than those who had two children. The results of this study are supported by Arsila's research (2014) which stated that there is a relationship between the number of children and the decision to use birth control. In another study, couples with a low number of living children had a tendency to use contraceptive methods with low effectiveness, while couples with many living children had a tendency to use high effectiveness contraceptive methods (Purwoko 2000). This is supported by the research results that the increasing use of vasectomy is due to the increasing number of children and increasing age (Sharma et al. 2013).

The other factor that had a correlation with the selection of a vasectomy was age. There were respondents who had two children and used vasectomy; this is probably due to the age of the respondents. According to Manuaba (2009), the age of 35 or more is the time for terminating reproduction. This statement is also concordant with the age range of the vasectomy group for this research. Participants who are 30 years old or more tend to use the long-term effectiveness of contraception.

The frequency distribution of health resources and infrastructure availability showed that more respondents positively assess health infrastructure. This indicates that most respondents have easy access to a vasectomy. But from the questionnaire, analysis showed that more respondents answered that there is no place to get a vasectomy around their home, as well as a few respondents who get explanation about vasectomy. The availability of health resources and health infrastructure affects the tendency to participate in vasectomy. It was common that the respondents did not participate in vasectomy due to the unavailability of resources and infrastructure. Healthcare is one of the parameters for determining the health status of the community (Tangkilisan et al. 2015); also, Ariyanti (2016) in her study said that the availability (quantity and distribution) of health resources contributes towards achieving family planning programs. Lawrence Green (1991) in Nursalam (2013) also stated that one of the factors that influences health behaviour is the availability of health resources and infrastructure. So, the quality of access to family planning services is one important element in achieving reproductive health services (Saifuddin 2010).

Another fact obtained through this study is that the majority of respondents did not ever receive health education about contraception or vasectomy. This is because the majority of respondents worked as farmers, with most of their time spent on agricultural land when health centre services were open so that most respondents could not get health counseling. Respondents who had no health education about vasectomy showed a lack of information about vasectomy, which causes the respondents to tend to avoid vasectomy. However, based on the result, a high level of knowledge about birth control and vasectomy after getting health education does not guarantee a person will participate actively in vasectomy. The expected outcome of health promotion is a change in health behaviours, or behaviour to maintain and improve health levels (Notoatmodjo 2012).

Although many respondents said that they never got health education, the majority agreed that health workers already had a positive attitude and behaviour. The attitudes and behaviours response of the health workers was reflected in the questionnaire in which most respondents said that health workers are kind to explain vasectomy. Attitudes and behaviour of health workers affects whether 
the client follows the advice given by health workers (Notoatmodjo 2003). But, the statistical result showed something different. It showed that health care attitude and behaviour had no correlation with vasectomy selection. This might indicate that the most important things to come out of the performance of a health care provider are real action, how to stimulate awareness of health among the community, not just exhibiting a kind attitude and behaviour.

The last factor obtained as a factor that affects a man's decision to use vasectomy was family support. Based on the answers to the questionnaire, respondents agreed that planning the number of children was part of the family's emotional support. Men who still had minimal support from the family cited informational support. Lack of information support was given by the families because they lacked knowledge and there were many respondents from a low social economic level. According to Putri et al. (2016) family support was affected by a family's ability to cover what they need. The family fulfillment capabilities related to income level or a family's socioeconomic level, where families from a higher socio-economic level give better family support. Family support, according to Friedman (2010), is an attitude, a family perception towards other members, with information, appraisal, instrumental and emotional support. These types of support are what categorise family support received by respondents.

This study found that respondents who get good support from families participate more actively in vasectomy. If the respondent does not get the support and consent from his wife, vasectomy is not done. Family support is indicated by a form of interpersonal relationship which includes attitudes, actions, and acceptance of family members so that the family members feel comfort (Friedman 2010). The results of this study are supported by previous studies conducted by Widoyo (2010) and Muklison (2015) where there is a significant correlation between family support (wife) and vasectomy selection. Limitations of this study are that most of the respondents are people who participate in government programs. The program is a mass vasectomy program that aims to launch the vasectomy program in the East Lampung Regency.

\section{CONCLUSION}

Attitude, the number of children, age, health resources and infrastructure availability and family support are factors that affect men's decisions to select vasectomy, while knowledge, health education, attitude and behaviour of health workers are not factors for someone to participate in vasectomy.

Nurses are expected to arrange interventions to increase men's interest and motivation to participate in vasectomy actively. The intervention also needs to be complemented with affordable facilities and active cadres engagement.

\section{REFERENCES}

Amory, J.K., 2016. Male contraception. Fertility and Sterility, 106(6), pp.13031309. Available at: http://linkinghub.elsevier.com/retrieve/pii /S0015028216627449 [Accessed October 13, 2016].

Anderson, R.A. \& Baird, D.T., 2002. Male Contraception. Endocrine Reviews, 23(6), pp.735-762. Available at: https://oup.silverchaircdn.com/oup/backfile/Content_public/Jo urnal/edrv/23/6/10.1210_er.20020002/3/edrv0735.pdf?Expires $=14975123$ $14 \&$ Signature $=O W v Y j L W H f Q 011$ SCXy UGv8QKxX8jTATM4z3UIZXDdoL12j Y8aFNIoG9dQq6rhPRCTD7i3pBYAKV Z079HRVx7UA8rDvvcI2-

EfEvlcNGiOtevYmXkx [Accessed September 11, 2016].

Badan Kependudukan dan Keluarga Berencana Indonesia (BKKBN), 2016. Laporan Kinerja BKKBN Tahun 2015, Jakarta: Badan Kependudukan dan Keluarga Berencana Indonesia (BKKBN). Available at: https://www.bkkbn.go.id/pocontent/uploads/LAKIP_BKKBN_2016_ 1.pdf [Accessed September 27, 2016].

Bunce, A., Guest, G., Searing, H., Frajzyngier, V., Riwa, P., Kanama, J., Achwal, I., 2007. Factors Affecting Vasectomy Acceptability in Tanzania. International Family Planning Perspectives, 13(1). 
Available

at:

https://www.guttmacher.org/sites/default/ files/pdfs/pubs/journals/3301307.pdf

[Accessed October 18, 2016].

Chang, Y.-H. et al., 2015. Economic fluctuation affects vasectomy utilization: A?single-institution study. Urological Science, 26(3), pp.214-217. Available at: http://linkinghub.elsevier.com/retrieve/pii /S1879522615002298 [Accessed October 15, 2016].

Friedman, M.M., 2010. Buku Ajar Keperawatan Keluarga : Riset, Teori dan Praktek. Jakarta: EGC.

Manuaba, I.A.C., 2010. Ilmu Kebidanan, Penyakit Kandungandan KB: Untuk Pendidikan Bidan. Jakarta: EGC.

Mubarak, W., 2007. Buku Ajar Keperawatan Komunitas. Jakarta: CV. Sagung Seto.

Muklison, A.P., 2015. Faktor-Faktor yang Mempengaruhi Masyarakat dalam Menggunakan Kontrasepsi Vasektomi di Kabupaten Tulungagung. Swara Bhumi, $1,51-57$.

Notoatmodjo, S., 2003. Promosi kesehatan dan perilaku kesehatan. Jakarta: Rineka Cipta.

Notoatmodjo, S., 2012. Promosi Kesehatan dan Perilaku Kesehatan (1st ed.). Jakarta: Rineka Cipta.

Nursalam, 2013. Metodologi Penelitian Ilmu Keperawatan: Pendekatan Praktis (3rd ed.). Jakarta: Salemba Medika.

Pekalongan, P., 2015. Laporan Profil Puskesmass Pekalongan. Lampung Timur.

Pratiwi, N., 2011. Pengaruh Faktor Sosial, Ekonomi, dan Demografi Terhadap Jumlah Anak yang Pernah Dilahirkan Hidup di Kecamatan Pesantren Kota Kediri. Surabaya.

Purwoko, H., 2000. Perbandingan
Penerimaan Antara Akseptor Vasektomi dan Akseptor Sterilisasi Tuba. UNDIP.

Putri, M.A., 2016. Psycoeducative Family Therapy Mempengaruhi Pengetahuan, Dukungan Keluarga dan Stigma Kusta. Jurnal Ners, 11, 88-98.

Saifuddin, A.B., 2010. Buku Panduan Praktik Pelayanan Kontrasepsi. Jakarta: Yayasan Bina Pustaka Sarwono Prawirohardjo.

Sharma, V. et al., 2013. Vasectomy demographics and postvasectomy desire for future children: results from a contemporary national survey. Fertility and Sterility, 99(7), pp.1880-1885. Available at: http://www.sciencedirect.com/science/art icle/pii/S0015028213003233 [Accessed November 11, 2016].

Wespes, E., 2014. Vasectomy in Male Contraception and its Reversal. European Urology Supplements, 13, pp.68-72. Available at: http://ac.elscdn.com/S1569905614000190/1-s2.0S1569905614000190main.pdf?_tid=657ae40e-54cc-11e7$8 \mathrm{c} 12-$ 00000aab0f6c\&acdnat=1497862431_6b3 31f8ad75e07aa780646f18b0f 2184 [Accessed October 19, 2016].

Tangkilisan, M., 2015. Peran Sarana Pelayanan Kesehatan Terhadap Kejadian Malaria di Kecamatan Silian Raya Kabupaten Minahasa Tenggara. Universitas Sam Ratulangi.

Tedjo, L., 2009. Faktor-Faktor yang Mempengaruhi Pemilihan Kontrasepsi yang Digunakan pada Keluarga Miskin. Universitas Diponogoro.

Widoyo, R., 2010. Faktor yang Mempengaruhi Pemilihan Vasektomi Sebagai Metode KB Pria di Kecamatan Luhak Nan Duo Kabupaten Pasaman Barat Tahun 2010. Universitas Andalas. 